\title{
Lecturas cinematográficas de Cinco metros de poemas: un acercamiento intermedial a la obra de Carlos Oquendo de Amat*
}

Recibido: 19/09/2019| Revisado: 03/03/2020 | Aceptado: 17/03/2020

DOI: 10.17230/co-herencia.17.33.8

\section{Elena Guichot-Muñoz**}

eguichot1@us.es

Resumen La investigación humanística adquiere un nuevo matiz en los análisis que confrontan lenguajes de distintas disciplinas artísticas. Por esta razón, este artículo se propone un acercamiento analítico intermedial a la obra Cinco metros de poemas de Carlos Oquendo de Amat, partiendo del hallazgo en su poesía de estrategias fílmicas extraídas de la semiología del discurso cinematográfico. Este proceder analítico arroja luz sobre el complejo virtuosismo de su obra, aplicando las teorías del desplazamiento de la cámara y del montaje a sus poemas. De ahí, se observa cómo el autor logra combinar las Estéticas de Jean Epstein, las técnicas de un film abstracto, con una hermenéutica profunda sobre el devenir de los tiempos. Con un arte similar al montaje armónico de la obra de Eisenstein, la obra logra implicar al "espectador" intelectual y emocionalmente gracias al complejo ensamblaje de sus cinco metros de poemas.

\section{Palabras clave:}

Oquendo de Amat, poesía, cine, intermedialidad, literatura latinoamericana, montaje.

\section{Cinematographic Interpretations of Cinco metros de poemas: An Intermedia Approach on the Work of Carlos Oquendo de Amat}

\footnotetext{
Abstract Humanistic research acquires a new nuance in the analyses that involve languages from different artistic disciplines. Therefore, in this article, an intermedia analytical approach to the work Cinco metros de poemas by Carlos Oquendo de Amat is aimed at, starting from the movie strategies found in his poems, extracted from the semiology of the cinematographic discourse. This analytical point sheds light on the complex virtuosity of his work, applying the theories of camera
}

* Este artículo hace parte del proyecto TRANS.ARCH Archives in Transition: Collective Memories and Subaltern Uses, del programa H2020, ID: 872299 de la Unión Europea.

** Doctora en Filología Hispánica y Profesora del Departamento de Didáctica de la lengua y de la literatura de la Universidad de Sevilla, España. ORCID: 0000-00016017-8837 
movement and production in his poems. Thus, it is observed how the author achieves a combination of the Aesthetics of Jean Epstein and the techniques of an abstract movie, with deep hermeneutics about the evolution of time. With artistry similar to the harmonic production in the work of Eisenstein, this work is successful in involving the "spectator" intellectually and emotionally thanks to the complex staging of its five meters of poems.

\section{Keywords:}

Oquendo de Amat, poetry, movies, intermedia, Latin American literature, montage.

tú que llevabas prendido un cine en la mejilla Carlos Oquendo de Amat

\section{El arquitecto de imágenes}

En 1895, los hermanos Lumière le regalan a la humanidad la ingeniosa aparición del cinematógrafo: emerge entonces una nueva forma de ver el mundo. En 1923, Carlos Oquendo de Amat, poeta y visionario peruano, elabora en su poesía una gran película vanguardista que parece desafiar el espíritu innovador que traerá este nuevo lenguaje cinematográfico. Cinco metros de poemas (1927), escrito entre 1923 y 1925, es un libro-acordeón por su disposición especial: se abre desenrollando cinco metros con 18 poemas que configuran un despliegue de cuadros de palabras. Los hermanos Lumière nunca pudieron prever el éxito de su invención: este aparato, sucesor de la "linterna mágica", reproducía 16 imágenes por segundo, imágenes fijas con apariencia de movimiento que tenían como primera motivación crear un instrumento de laboratorio para registrar los cuadros cotidianos. El poeta peruano, con esa misma intuición certera, escribe "poemas inseguros como mi primer hablar", en los que, frisando apenas los 19 años, nos desgarra con su visión de la vida moderna.

Es un lugar común advertir que el poeta comienza jugando con la herencia de los caligramas (Sánchez, 1992), y con una producción cinemática heredada de Francia (Apollinaire, Soupault, Aragon). De hecho, "Film de los paisajes" aparece en la sección de ideogramas de la antología de poesía hispanoamericana del editor Antonio Cillóniz (1989). No obstante, Oquendo de Amat muestra una huella más compleja de las técnicas que el cine recién patentaba. Según Carlos 
Germán Belli (2013), la concepción de Cinco metros de poemas tiene su punto de partida en el pensamiento de Jean Epstein, quien en su estudio sobre La poesía de hoy: Un nuevo estado de inteligencia afirmó que "antes de cinco años se escribirán poemas cinematográficos: 150 imágenes en rosario en un hilo que seguirá la inteligencia" (1920, p. 127). Siendo o no la inspiración de Oquendo de Amat para el título de su obra, describe a la perfección estos casi cinco metros que observamos deslumbrados ante su caída de acordeón. Por esta razón, este artículo se propone un análisis particular que parte del lenguaje fílmico para desentrañar la hermenéutica del poeta peruano, heredero -acaso inconsciente- de las virtudes del séptimo arte.

A lo largo de la historia de la crítica, tanto literaria como cinematográfica, es una constante buscar paralelos estructurales entre el cine y la literatura, y en el caso de Oquendo de Amat ya se han analizado estas relaciones con distintas perspectivas (Ibáñez, 2017; Núñez, 2006; Pessis, 2014). En los estudios teóricos que aúnan cine y lenguaje, sin duda, se reconoce un esfuerzo por encontrar analogías en los textos de Aumont (2004), Carmona (1991), Casetti y Di Chio (1991), Peña-Ardid (1992) o Seymour Chatman (1990), aunque se incide especialmente en la novela, con la excepción de Urrutia y su ensayo magistral "Cine y poesía" (2000). Sin embargo, en este acercamiento, y haciendo un homenaje al autor que posiblemente originó el nombre de la obra de Oquendo, se tomarán, con el máximo rigor posible, las diferentes Estéticas que Jean Epstein menciona como planos que deben superponerse en la literatura y en el cine. Se contrastará, por tanto, la semiología cinematográfica con la poética, con el fin de evidenciar la consonancia de ambos lenguajes artísticos, en un afán por abordar la investigación humanística desde una perspectiva intermedial (Elleström, 2010; Frank, 1991; Higgins, 1967). La intermedialidad en este caso es entendida en relación con el paradigma interartístico, en contra del denominado "modelo topográfico", que piensa en las artes y los medios de comunicación "in terms of geographic areas delineated by borders" (Englund, 2010, p. 69). El establecimiento de fronteras en el estudio de las artes quiebra el espacio intermedial que tanta riqueza metafórica ofrece; por tanto, se propone un análisis que conjugue cine y poesía en aras de conseguir un acercamiento más esclarecedor a la obra del autor peruano. 


\section{Confluencias técnicas: la estética y los movimientos de cámara}

Tal vez, el primer crítico que indagó en las confluencias entre cine y literatura fue Sergei Eisenstein, cuyas palabras inauguran nuestro análisis aproximativo al poemario de Carlos Oquendo de Amat:

Hay escritores que escriben, diría yo, directamente en forma cinematográfica. Ellos ven en fotogramas. Más aún, en imágenes de fotogramas. Y escriben en forma de guion de montaje. Unos ven en forma de guion de montaje. Otros desarrollan hechos. Otros componen con metáforas cinematográficas. Algunos poseen todos los caracteres juntos (1972 [1933], p. 11; la cursiva es mía).

Para Eisenstein el montaje es un principio universal que llega a su culminación en el cine. Sánchez-Biosca (2009) define el concepto del montaje como aquel que dibuja "con mayor precisión el sentimiento dominante en las teorías de los años veinte, desde las primeras reflexiones cubistas y sus fracasados proyectos de un cine sinestésico hasta los planteamientos más desarrollados de un cine dadaísta o superrealista" (p. 96). Cinco metros de poemas es un montaje que nos atraviesa desde la portada, pues la imagen principal son cuatro máscaras o rostros que clavan su mirada en el lector (imagen 1):

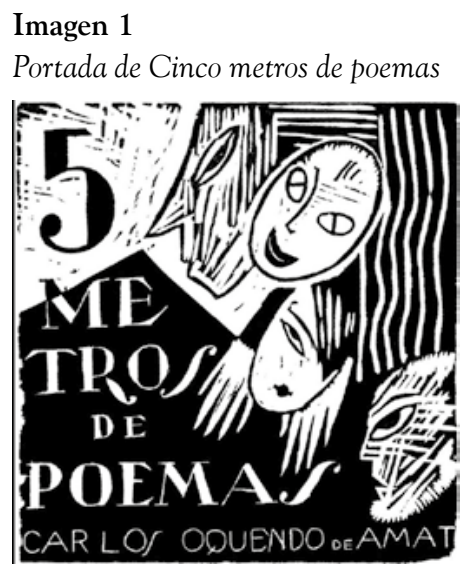

Fuente: Librería Sur (s. f.). [imagen adjunta]. https://bit.ly/2ONdIpY 
"Entre el espectáculo y el espectador, nada de barreras. No se contempla la vida; se la penetra” (Epstein, 1920, p. 123). Ya Ibáñez advierte que a partir de esta estructura flexible "los fragmentos devienen fotogramas [...]; la palabra, imagen; los poemas, movimiento" (2017, p. 175). Desde la carátula de este libro-objeto nos sentimos atrapados por esos rostros teatrales que evocan la diversidad de máscaras que nos encontraremos al desenredar el hilode esta tela poética. El descubrimiento de la vanguardia a corta edad provoca en Oquendo de Amat una búsqueda por un lenguaje propio, que extrañe la percepción del lector desde la misma portada, bebiendo del fotomontaje y la cartelística típica de la influencia propagandística de los años 20, cercana a la pintura de Picasso, Braque o Haussmann, entre otros. Su excepcionalidad nace de una renovación general que se da a comienzos del siglo xx en la intelectualidad del Perú, de la que forma parte nuestro autor:

Partiendo de esta primera renovación, a comienzos de los años veinte la oleada de ismos inundó con facilidad no sólo la capital -Lima- sino también, y como principal novedad, toda la costa y la sierra peruanas. Autores como César Vallejo, Alberto Hidalgo, Xavier Abril, César Moro o Carlos Oquendo de Amat son algunos de los nombres más sonoros de este cambio sustancial de innovación vanguardista, que tuvo como órganos principales de difusión las revistas Amauta (1926-1930), Boletín Titikaka (1926-1931), Poliedro (1926) o Trampolin-Hangar-Rascacielos-Timonel (1926-1927) (Valero, 2008, p. 308).

No obstante, uno de los rasgos que hacen que este autor tenga una insularidad poética respecto a sus coetáneos, es precisamente un recurso fílmico que propone el poeta puneño, y que contrasta con las premisas de la vanguardia: la Estética de la cercanía (Epstein, 1920, p. 123). Nos servimos en esta ocasión de la cinematografía para describir una herramienta con la cual consigue acercarnos a su intimidad, y a la nuestra, demostrando que no hace falta recurrir a la sentimentalidad para estremecer a un lector. Los Cinco metros de poemas funcionan como una cámara subjetiva, definida por la semiología cinematográfica de la siguiente manera:

Algunos realizadores tuvieron la idea de colocar la cámara en el lugar del héroe durante pequeños instantes con el fin de hacer compartir su punto de vista y, por tanto, permitir al espectador adaptarse a o mejor comprender sus sentimientos, su estado de ánimo [...] imágenes cuya subjetividad no era más que una mirada sobre el mundo exterior (Mitry, 1990, p. 64). 
Luis Monguió, de hecho, advierte cómo el poeta es raro "por cuanto el vanguardismo no se distingue por su sentimiento" (2004, p. 83), y sin embargo, encuentra la presencia de una variedad de sustantivos referentes a las calidades humanas de la naturaleza, a las partes del cuerpo y adjetivos y nombres como "ángel (5 veces), sonrisa (4), besos (3) [...] Suspiro, ternura, amistad [...]" (2004, p. 83). Así, Oquendo cumple con la primera premisa que propone Epstein: logra acercarse al lector a través de su mirada más íntima, que comienza en la dedicatoria de los poemas a su madre.

Sin embargo, enseguida aborda un movimiento propio del séptimo arte: la cámara permanece fija y gira sobre su eje pasando del hombre íntimo de "Aldeanita" o "Madre campo", a las visitas por los ambientes convulsos de las ciudades, como en el caso de "New York" o "Amberes". Entre los movimientos de la cámara podemos destacar el de la panorámica, que se identifica con la visión de un hombre inmóvil a derecha e izquierda o incluso mirando hacia arriba o abajo, pero sin desplazamiento. En el cine se usa la panorámica para reflejar el alcance del ojo del ser humano, movimiento que seguimos asimismo con la colocación de las letras de los pasajeros cayendo en catarata, en el poema "Amberes", o el ascensor que desciende en el poema "Réclam". Ibáñez (2017) emparenta este uso de la palabra con un "medio de locomoción capaz de activar el trance, la ensoñación y el desplazamiento", con la consecuencia de transformarnos "en lectores nómadas" (p. 178).

Definitivamente, los movimientos remiten a metodologías experimentales del cine de vanguardia, como la denominada por Villaplana y Ortuño (2018) "Film-poem como abstracción". En esta categoría estos autores agrupan a cineastas como Abel Gance, Germaine Dulac, Marcel L'Herbier y Jean Epstein, que muestran una obsesión por "la cadencia del montaje, obsesivo y rítmico" $(2018$, p. 6), aspecto intrínseco a la poesía de Oquendo. Un ejemplo de ello se ve en su poesía con el símil cinematográfico del travelling o desplazamiento (Ibáñez, 2017, p. 179), movimiento mediante el cual el objetivo aparece fijo y se desplaza con el móvil sobre el que está situado. Este deseo de otorgar movimiento a lo estático surge desde el mismo formato del libro-fuelle que ofrece dos opciones para leer u observar: una lectura canónica que avanza página tras página, o una lectura que desenvuelve su contenido como un bandoneón (cfr. Oviedo, 2006). 
Asimismo, tal y como apunta Monguió (2004), es curioso cómo los verbos que más se repiten en estos Cinco metros de poemas son los relativos a la quietud (ser, estar y haber), y los verbos "que implican movimiento" (2004, p. 82), lo que desemboca por tanto en un equilibrio entre presencia y dinamismo. Nos referimos al primer poema acéntrico que descubrimos tras un "Intermedio" y dos poemas amorosos: "Film de los paisajes". Tal y como afirma Ibáñez, "El pliegue/poemario/libro/film, al igual que en las antiguas proyecciones o espectáculos teatrales, nos invita paródicamente a una pausa" (2017, p. 180). La estructura de este poema moviliza los ojos del lector que observa una panorámica de un paisaje cubierto de imágenes capaces de evocar un desplazamiento espacial, temporal y rítmico. Además, se encuentran también estos dos procedimientos en un poema que Jean Epstein podría definir con la siguiente cita: "Un desplazamiento de planos desuela mi equilibrio" (1920, p. 123). La mirada de Oquendo se traduce en un plural mayestático que reúne al lector y al observador en una misma acción:

Tocaremos un timbre

París habrá cambiado a Viena ${ }^{1}$

Vemos la sucesión de dos puntos geográficos y la imagen de la velocidad del sonido de un timbre: aspecto rítmico y temporal. El lector está de esta forma implicado en la visión de este nuevo paisaje que "se ha desdoblado". La disposición tipográfica de los versos hace que la vista pase de un lugar a otro y se coloque en distintos puntos como una cámara que mira hacia arriba y hacia abajo:

\section{todos somos enanos}

Las ciudades se habrán construido

Sobre la punta de los paraguas

(Y la vida nos parece mejor porque está más alta)

1 Oquendo de Amat (1985). Se cita la edición de Cinco metros de poemas de la editorial Orígenes. Las páginas de este texto no están numeradas, por lo que no se puede poner el número de página en ninguna de las citas. 
El sentido de inferioridad de Oquendo ante este mundo del progreso es traspasado al lector con el plural de primera persona que nos convierte a todos en "enanos": proceso de igualación. Bajamos los ojos y nos encontramos con la inestabilidad de vivir sobre una ciudad que se soporta en "la punta de un paraguas". Y a pesar de todo, rompe con la paradoja del siglo Xx, fruto de la llegada del capitalismo: la sensación general que se desprende de que la vida está mejor "porque está más alta". Por medio de imágenes espaciales imposibles nos envuelve en una descripción crítica de la ciudad moderna que iguala y empequeñece al individuo, y con una afluencia de metáforas que buscan la correspondencia imposible entre la naturaleza y la tecnología: "Las nubes son el escape de gas de automóviles invisibles". Por esta razón "se ha desdoblado el paisaje" que, construido con materiales efímeros, absorbido por la inestabilidad y el vértigo de la segunda revolución industrial, puede esfumarse como el polvo: "Esto es insoportable/un plumero/para limpiar todos los paisajes".

Como podemos observar, el cotejo del campo y la ciudad, del paisaje natural y el artificial, será una constante en este autor, cuya biografía se sustenta entre sus visitas al terruño, a su Puno natal, y su experiencia de crecimiento en la capital limeña, hostil por su condición precaria. Podemos descubrir en estas líneas cierto aire de desencanto del joven poeta, cuya inestable vida en la capital queda reflejada en textos como "El poema del manicomio". No obstante, en "Film de los paisajes" el juego visual y la dinamización constante de imágenes termina consiguiendo que la poesía no se embargue de pesimismo y parezca quedar "despojada de altas pretensiones intelectuales, espirituales y artísticas” (Pessis, 2014, p. 17).

Este desplazamiento lúdico registra una cantidad infinita de imágenes que marcan un sesgo ensoñador en la obra, no en vano calificaba Vargas Llosa a Oquendo de "osado arquitecto de imágenes, un fulgurante explorador del sueño" (1983, p. 132). Este mismo procedimiento lo volvemos a observar en el poema acéntrico de "Amberes", ciudad que jamás visitó. La imaginación del lector se ayuda del poema visual -recordemos que mencionamos las letras que bajan una tras otra- para crear una imagen en la que unos pasajeros americanos parecen descender de un trasatlántico bajo la mirada atenta y fija de esas mujeres con "ojos receptivos de celuloide". 
Podemos reconocer en estos poemas otros recursos que más tarde usarán sin cesar los cineastas para conseguir penetrar en la intimidad del espectador -como la división escalar- "desde el primer plano al plano lejano" (Mitry, 1990, p. 40).

No obstante, los recursos cinematográficos de la técnica coinciden sobre todo con los de Oquendo de Amat por la necesaria amplitud de miras que tenía el poeta, cuya urgencia por un lenguaje innovador procedía de la propia necesidad de explicar algo que iba más allá de su tiempo, por su "ambicioso desatino de inventar realidades verbales” (Vargas Llosa, 1983, p. 134). Begoña Pessis García detalla con precisión la significatividad de esta coincidencia entre el cine y la poesía del autor peruano:

El cine se presta fácilmente para vehicular su compleja sensibilidad, porque permite disponer en una relación inusitada sus materiales (como el tiempo, el espacio y las imágenes). En esa dirección, no es majadero recordar las palabras de Arnold Hauser al respecto, quien plantea que en el cine el espectador asiste a un mundo donde los límites entre espacio y tiempo son fluctuantes. En el cine el espacio es dinámico, fluido e ilimitado, adquiere un carácter temporal y sus partes no comparten el mismo valor (el primer plano, por ejemplo, rebasa los límites de lo espacial y su uso provoca efectos en el desarrollo temporal de una película). El tiempo, a su vez, asume una dimensión espacial; por un lado, pierde su ininterrumpida continuidad, su dirección irreversible y, por otro lado, tiene la posibilidad de ser detenido, invertido, repetido y superado (Pessis, 2014, p. 7).

En la poesía de Oquendo de Amat podemos detenernos en pareados dispuestos en la página con independencia, o asumir la corporalidad de una oración que alude a los sentidos estirándose y dilatándose en el espacio de la página, como la siguiente: "e 1 c a 1 o r e s c o m o u n p e n s i o n i s t a”. Estableciendo una comparación con la técnica del primer plano, Oviedo Pérez de Tudela (2006) propone una lectura particular de la tipografía de tres poemas: "Jardín", "Poema" y "Obsequio". Vincula tres tipografías que llaman la atención del lector por su formato en negrita y en mayúsculas, y por su posición; se ubican las tres en el último verso: "LA LUNA CRECERÁ COMO UNA PlANTA" (de "Jardín"), "QUe CANTA EN todas las RAMAS de la maÑANA" (de "Poema"), y "JARdinera DE MI BESO" (de "Obsequio"). Esta autora propone que su tipografía especial "se pudiera interpretar a manera de imagen subliminal que 
permanece en la retina y permite establecer la unión entre los tres poemas" (2006, p. 4). En estos recursos podemos ver un acercamiento en primer plano o "imágenes captadas con zoom" (Ibáñez, 2017, p. 185) que se dispersan y se repiten a lo largo de todos los poemas de Oquendo: la luna, el canto, el beso. Al igual que una cámara, acerca su objetivo a una realidad que quiere destacar, a un tema que tiene presente a lo largo de todo el poemario: el amor. El poeta, tipográficamente, reduce y amplía las letras para crear una imagen fija dentro del cuerpo dinámico del poema, y de este modo nos devuelve subrepticiamente uno de sus demonios vitales, aprovechando la terminología vargasllosiana: la amada.

\section{Confluencias temáticas: el amor y la máquina}

No es extraño pues que Eva Valero Juan clasifique a la amada en la obra de Oquendo como una tercera geografía "en la que la naturaleza hace de la mujer una fuente de belleza" (2008, p. 314). La mujer aparece como fuente creadora, como una manifestación que provoca transformaciones en la naturaleza, en el universo. De hecho, si extraemos del libro de poemas otra de las negritas en mayúsculas y en verso final de "El poema del mar y de ella", descubrimos la cualidad extraordinaria de esta amada: "y eres más que tu delantal y tu libro de letras/ eres una sorpresa perenne/ DENTRO DE LA ROSA DEL DíA”. Esta habilidad creacionista, propia de la naturaleza, se repite junto a otra alusión vinculada a la amada, tal y como advierte el crítico Sánchez Rodríguez (1992): el discurso. La amada canta, dice, y lleva "prendido un cine en la mejilla". Además, ese carácter creador también tiene relación con el "binomio madre-niño" (Pessis, 2014, p. 17) que reitera constantemente el poeta puneño. La magia del cine conforma la imagen femenina, que en los principios del cinematógrafo deambula entre lo sobrenatural y lo cotidiano. En otros textos tendrá ese carácter cosificador, que convierte a la mujer en un objeto: "Yo tenía cinco mujeres/ y una sola querida", "Mary Pickford sube por la mirada del administrador", "tus sonrisas maravillosas sombrillas para el calor". La mujer, en cualquier caso, se ve polarizada entre dos imágenes intangibles: 
[...] las mujeres pululan entre imágenes ancladas en el juego binario de la representación occidental. Esto es, el discurso cinematográfico, principalmente el llamado cine narrativo clásico, tiende a través de su estructura narrativa y representacional a dividir el papel de la mujer en: mujeres negociables (madres, hijas, esposas...) y mujeres consumibles (prostitutas, vampiresas, golfas...) y coloca a las primeras por encima de las segundas, estableciendo así una jerarquía de valores en los papeles otorgados (Siles, 2000, § 12).

A pesar de que Carlos Meneses (1973, pp. 20 y 44) ya nos advierte sobre el desconocimiento de una mujer concreta en su vida, ${ }^{2}$ y por tanto, de la inexistencia de un detalle realista que conecte la historia del autor con la realidad, el detalle estético insuperable para plasmar el amor es "el contraste entre lo cotidiano y lo mágico -siempre en la esfera de lo privado- [...] así como la belleza plástica de la situación" (Sánchez, 1992, p. 261); cualidades que son intrínsecas al lenguaje cinematográfico de principios del siglo Xx. No obstante, esta mezcla entre lo cotidiano y lo fantástico también debe su aparición a la llegada de la publicidad, otro de los temas importantes en la obra de Oquendo de Amat. Es a principios del siglo pasado cuando "las imágenes de cine y la publicidad codifican el amor romántico en cuadros visuales de intimidad erótica, ocio y lujo" (Illouz, 2009, p. 36). Se produce la "secularización del amor", y se asocia el amor y el consumo, lo que da pie, según Illouz, a la "romantización de los bienes de consumo" (2009, p. 53). Desde el poema más íntimo, "Aldeanita", se introducen las monedas ("dos reales") para construir una metáfora pura sobre los ojos de la amada. El paisaje romántico también sucumbe a las necesidades del consumismo en "Réclam", donde la luna, inseparable de Eros en la literatura, "está de compras". Este poema muestra una visión del amor que bien podría responder al estereotipo del sueño americano que revela la publicidad de los años 50:

2 En el apartado "Extravío en la oscuridad del mito" de su libro Tránsito de Oquendo de Amat 1905-1936, Meneses menciona el "desconocimiento de la mujer amada" (1973, p. 20). Luego, en "Intimidad del poeta", también sugiere que Oquendo de Amat no tenía una referencia concreta de mujer, aludiendo al testimonio de Méndez Dorich: "El tema de la mujer en los poetas es un tema constante y no se necesita estar enamorado para hablar de ella" (citado por Meneses, 1973, p. 44). 
El poema es en sí mismo un breve montaje de atracciones, como en el cine de George Meliès. Los protagonistas son la luna y el sol personificados. La luna, como flâneuse -contraparte femenina del flâneur benjaminiano- está de compras en una ciudad viviente, que se mueve al ritmo entrecortado de los cláxones. El sol, como un letrado pequeñoburgués, lee la ciudad desde su asiento en el tranvía (De los Ríos, 2007, p. 95).

En "Film de los paisajes", el "paisaje es de limón y mi amada quiere jugar al golf con él", imagen que conduce directamente a la mercantilización de un espacio romántico. La alusión a la amada parece tener múltiples lugares de enunciación, como si el yo lírico cambiara su percepción del amor según la atmósfera que lo rodea.

En esta polifonía, entendida en el sentido bajtiniano como "la orquestación de las voces en diálogo abierto, sin solución” (Bubnova, 2006, p. 107), Oquendo de Amat juega con su dominio del objetivo, y dirige nuestra mirada a su antojo, incluso en un poema en el que decide cedernos la cámara a nosotros: "Comedor". Suelta los ojos en "la percha del bastón" mientras que un camarero lo mira. A pesar de ser uno de los poemas que responde a un ámbito más íntimo, curiosamente en el punto de vista no aparece la primera persona ni tan siquiera en un plural común:

\section{Cansancio}

Los ojos se han colgado de la percha del bastón

\section{La mirada \\ Es un camarero}

Las imágenes que se reflejan en este poema recuerdan la fabulación chaplinesca en la que se alteran todos los objetos. Esta ilogicidad textual cobra sentido bajo el "cansancio" que manifiesta el sujeto poético en el primer verso; lo general y lo concreto se unifican siguiendo la teoría del acto poético de Kristeva: "comme si l'unicité du signifié poétique était à ce point accentué que celui-ci, sans passer par l'individuel, mais en se dédoublant (à la fois concret et général), rejoignait le tout" (1968, p. 41). Esto entra en armonía con otra de las premisas de Jean Epstein, la Estética de sugestión: "La cualidad esencial del gesto en la pantalla es la de no concluirse" (1920, p. 124). La mirada ahora deambula del observador aletargado que deja los ojos en el perchero, a la mirada activa del camarero. De esta concreción de lo no finito, del relevo constante, pasamos al plano general al extender 
los casi cinco metros de poemas, donde obtenemos un aparato poético que se estira y se encoge con los únicos límites que tiene el papel, la debilidad de la materia. Así su poesía no es sentenciosa, sino abierta, y juega siempre con el dato escondido que está por venir:

De todas las artes posibles el cine es el que más juega con lo oculto. Si reparamos en la imagen de un film [...] vemos que hay cosas que no están en la pantalla pero que están cerca, sólo elididas por momentos, solapadas, dispuestas a entrar en un cuadro por cualquiera de sus cuatro segmentos (Hernández, 2005, pp. 121-122).

En el cine esta estrategia se denomina fuera de campo, es un "no visto" que sin embargo está presente, disponible. La memoria y la percepción del espectador reconstruyen estos espacios, los imaginan, y conciernen a los lectores; en definitiva "será el lector/observador/ espectador quien, a partir de un trabajo productivo, complete el texto/imagen/fotograma haciendo visible lo invisible" (Ibáñez, 2017, p. 178). En los poemas de Oquendo de Amat se puede percibir algo más allá de lo plasmado en el papel. Esta evidencia parece un tópico de la poesía, pero lo curioso de la poética del autor peruano es la forma de lograrlo. Este recurso lo consigue con gran maestría gracias a la combinación de poema verbal y visual: las imágenes móviles, las diversas notaciones en forma de cartel, las variaciones tipográficas; todo se consume en un juego visual laberíntico que favorece la comprensión del mundo interior de Oquendo. Observamos en sus huecos vacíos una presencia encubierta: nos lanzamos a la búsqueda del trasfondo de su mensaje. La fragmentación, elemento esencial del montaje cinematográfico (Sánchez-Biosca, 1996), es un fundamento propio del futurismo de Marinetti, o del creacionismo de Huidobro, pero en Oquendo adquiere la sensación inmediata de estar percibiendo un texto fílmico.

Como ejemplo paradigmático de esta estrategia, el poema "New York" nos introduce en el maravilloso y terrorífico mundo de la Modernidad y del cine en un sinfín de imágenes que perturban nuestro tradicional punto de vista. Podríamos asimismo enlazarlo con la Estética de la rapidez mental de Epstein: "Para que la comprensión no naufrague, es preciso violentar en diez segundos las entradas de diez metáforas" (1920, pp. 125-126). Este poema es un espectáculo visual que traduce el encantamiento y la velocidad de los tiempos 
modernos. El lector no sabe dónde fijar los ojos: en el principio "Los árboles pronto romperán sus amarras/ y son ramos de flores todos los policías", y en el centro, como una gran avenida en medio de la ciudad, expone:

$\begin{array}{lll}\text { T } & \\ \text { I } & \\ \text { M } & \\ \text { E } & \\ & & \\ \text { Los teléfonos } & \text { Diez corredores } \\ \text { son depósitos de licor } & \text { S } & \\ & & \\ \text { M } & \\ \text { O } & \\ \text { N } & \\ \text { E } & \\ \text { Y } & \end{array}$

Y hacia abajo nos encontramos una imagen sintética del cine: CHARLESTON RODOLFO VALENTINO HACE CRECER EL CABELLO NADIE PODRÁ TENER MÁS DE 30 AÑOS

El cine como la fiesta de la eterna juventud mientras Mary Pickford, la novia de América, "sube por la mirada del administrador". Describe con unos pocos versos la exhibición y producción cinematográfica, muestra cómo los directores y los actores son conscientes del poder que poseían las imágenes animadas para atraer consumidores y plasmar sus deseos, y los títulos de las películas se leen ya como titulares de prensa. Tras mostrarnos este poema-rascacielos, nos enfrenta al dato escondido, a esa imagen fuera de campo: la cruda realidad se presenta con una disposición tipográfica en negrita y extendida que frena la velocidad del ritmo poético, de la modernidad:

A Q U Í COMO EN EL PRIMERO NADA SE SABE DE NADA

Nada es casual, aunque parezca nacido de la entropía. Aquí (arriba) como en el primero (primer piso), nada se sabe de nada. Las subidas y las bajadas físicas tienen su relación con la vida social: la 
subida del piso 28 al piso 100 en el ascensor, elemento recurrente en la poesía de Oquendo, es una metáfora de la drástica escalada en la clase social (Sales, 2010). El tiempo del trabajo retrasa los relojes, la ciudad uniforma como la mañana que "se va como una muchacha cualquiera", y nos deja un cartel que transmite la alienación del ser humano:

SE ALQUILA

ESTA MAÑANA

Jean Epstein alude a otro tipo de estética que denomina la Estética de sucesión, "rápida y angular, tiende hacia el círculo perfecto del simultaneísmo" (1920, p. 125). Las imágenes caen, se traban, se mezclan, se enrolan en una contigüidad y se descomponen en figuras imposibles. Pero todas estas imágenes no tendrían sentido sin esta estructura desestructurada. Jean Mitry cita un texto de la obra Film Form, de Eisestein, que logra definir la técnica de montaje que se refleja en la poética de Oquendo:

El plan, dice, no es un elemento del montaje, es una célula. Lo mismo que la división de células produce una serie de organismos diferentes, la división en planos -su colisión, su conflicto- hace nacer los conceptos [...] $\mathrm{Si}$ el montaje debe ser comparado a algo, prosigue Eisestein, las colisiones sucesivas de un conjunto de planos pueden ser comparadas a una serie de explosiones en un motor de automóvil. Lo mismo que estas imprimen movimiento a la máquina, el dinamismo del montaje da impulso a la película y la conduce a su finalidad expresiva (1990, p. 14).

Los "fotogramas" del poema "Réclam" no son simplemente imágenes en movimiento desprovistas de soporte, muy al contrario, desde el momento en el que estas fueran desposeídas de su "plano" ya no existiría el poema. Este texto se configura como ejemplo del lado más oscuro, y a su vez subversivo, de todo el poemario. El título nos conduce a un reclamo publicitario que veremos repetido a lo largo del poema en numerosas imágenes, dándonos la impresión de que todo se vende: "se botan programas de la luna", "película sportiva pasada dos veces", "el policeman domestica la brisa”. El consumismo de la ciudad devora al ciudadano y va más allá, pues la luna, el sol, el viento, son atraídos por ese "réclam". La urbanización del discurso natural se consigue gracias a la cotidianeidad de las acciones de los elementos naturales. El montaje del poema consiste 
en la disposición vertical de estos cuadros cotidianos de la luna, el sol, el viento, hasta introducirnos en forma de embudo perfumado a las "miradas internacionales". La captación simbólica de la brisa, la sinestesia del ruido de los cláxones, que pone los vestidos azules, dibuja el contexto en el que el poeta y el poema conviven. Anuncia la novedad: la máquina sirve al hombre; "Todos los poetas han salido de la tecla U. de la Underwood". De hecho, el ascensor de nuevo será el protagonista que une la creación natural con la máquina, por medio del consumo: "Un ascensor compró para la luna 5 metros de poemas". Precisamente encontramos el título de la obra en un poema que no puede prescindir de ninguna de sus imágenes para llegar a este último y grandioso fin. Tynjanov propone una superposición de conceptos cinematográficos y claves de la estilística de la vanguardia poética para explicar este proceso: las imágenes "alternan como un verso, una unidad métrica sucede a la otra"; el cine "realiza saltos de una imagen a la otra, como la poesía de una línea a la siguiente" (1971 [1927], p. 120).

\section{Conclusión: la necesidad de "réclam" en los tiempos modernos}

Tras la lectura de los Cinco metros de poemas, no es difícil afirmar que el escritor peruano logra plasmar imágenes que la ambición del cine pudo captar ya tardíamente. Es decir, la palabra en Oquendo de Amat libera, subvierte la realidad, sugiere, emociona, tal como hiciera más adelante el cine. Ya el crítico peruano Mirko Lauer expone en su obra Musa mecánica que José Luis Ayala, biógrafo de Oquendo de Amat, quería lanzarse a la creación de un librofilme "con páginas de celuloide" o una "cinta de cinemapoemas" (2004, p. 127). El cuidadoso montaje de Cinco metros de poemas activa, bajo la aparente incongruencia de elementos, un sentido poético de enorme expresividad. Como lo afirma Mitry (1990) en su libro La semiología en tela de juicio (cine y lenguaje), el montaje tiene un desarrollo que en lugar de ser continuo, fundado en la linealidad, es discontinuo, basado en el choque de elementos casi simultáneos que engendran ideas con una sensación final de armonía. Las connotaciones de las imágenes que plantea Oquendo están siempre por descifrar, pero la 
confrontación de las mismas nos ofrece metáforas que solo existen como tal en la mente de cada uno, están aisladas de todo referente. Por ello a veces parece que no estamos en el mundo del lenguaje poético sino en un apasionante film: sentimental, realista, erótico, absurdo, cómico, sarcástico.

Sin embargo, el juicio político también se deja sentir en su poesía, pues destaca "un modo de vida en la ciudad que resulta esencialmente ajeno a la experiencia urbana normalizada bajo el capitalismo reconsolidado mundialmente después de la Segunda Guerra Mundial” (Arteta, 2007, p. 304). Emparentado por la patria, y por una crítica al capitalismo más evidente, César Vallejo también deja huellas de la cinematografía de principios del siglo xx en su obra. Natalia Gómez (2008) rescata la presencia de la estética de Chaplin en sus Poemas humanos y destaca un aspecto que nos incumbe por las similitudes con la estética del poeta puneño: el uso del cuerpo en el "hombre-fábrica" (hombre en la acepción de ser humano): "Al igual que la máquina, el cuerpo se convierte en un artificio en el que los miembros realizan funciones de rendimiento económico y sólo son así valorados dentro del sistema de producción" (Gómez, 2008, § 8). En estos cinco metros de poemas, donde el tiempo es dinero ("Time is money"), "un marinero saca de las botellas cintas proyectadas de infancia": todo se enlata, todo se materializa, todo se consume.

Por tanto, en relación con la estética cinematográfica, al igual que Vallejo, es notable cómo el análisis visto desde el discurso fílmico aporta un matiz original: la técnica del montaje y el artificio poético de la "cámara" subrayan el tono crítico hacia los tiempos modernos que arroja el autor peruano. Se concluye que en su obra la humanidad pesa sobre la superficie, tesis que se confirma con la lectura intermedial del poema "Madre campo", donde la palabra de Oquendo permanece "primitiva como la lluvia o como los himnos" ante la figura maternal. Con este poema, Oquendo pasa de un espacio fílmico abstracto dedicado a los tiempos que vive, a un "film como poesía dialéctica" (Villaplana y Ortuño, 2018, p. 12), que muestra la matriz: "porque ante ti callan las rosas y la canción". Sin necesidad de buscar un efecto de realidad, consigue acercar al lector a unas emociones surgidas de ese choque de imágenes, que genera su propia dialéctica, al modo del montaje armónico de la obra de Eisenstein: 
[...] el montaje armónico es [...] un refinamiento de la tonalidad; hilando su propia metáfora, Eisenstein idea un montaje extraordinariamente complejo, donde cuentan todos los "estímulos" emocionales, incluso los más tenues, producto de los detalles visuales más sutiles, igual que en música nuestra impresión global de una obra no solo deriva del ritmo y de la tonalidad de la pieza sino también de los "armónicos", esas notas apenas audibles que le dan color (Aumont, 2004, p. 27).

Por medio de los artefactos discursivos mencionados, Oquendo de Amat logra implicar al "espectador" en contenidos revolucionarios. De hecho, la obra se cierra disolviendo esa tensión entre campo y ciudad, entre centro y periferia (cfr. Gómez de Tejada, 2017), con un poema que deja espacio al sueño ("Poema al lado del sueño"), como si jugáramos con un desenfocado de cámara, en el que se borraran los límites entre la realidad del pasado, impregnada de nostalgia ("en el tren lejano iba sentada la nostalgia"), y la ensoñación del presente:

$[\ldots]$

Tú estás aquí como la brisa o como un pájaro

En tus sueños pastan elefantes con ojos de flor

Y un ángel rodará los ríos como aros

Eres casi de verdad

[...]

Estos versos, parecidos a los espacios subconscientes de un cuadro de Dalí, muestran la "felicidad expresiva" (Monguió, 1954, p. 155) de este poeta, que asume su combate contra la falsedad de la realidad con una poesía plagada de virtuosismo cinemático $\mathbf{C}$.

\section{Referencias}

Arteta, A. C. (2007). Carlos Oquendo de Amat o el socialismo en tono menor. Revista de Crítica Literaria Latinoamericana, 33(66), 299-311. https://as.tufts.edu/romancestudies/rcll/pdfs/66/CAMPUZANO.pdf

Aumont, J. (2004). Las teorías de los cineastas. Paidós.

Belli, C. G. (2013). Imágenes impresas: "El libro como objeto estético". 5metrosdepoemas.com. https://bit.ly/2ZQLbpE

Bubnova, Tatiana. (2006). Voz, sentido y diálogo en Bajtín. Acta poética, 27(1), 97-114. https://bit.ly/30AH1Bp.

Carmona, R. (1991). Cómo se comenta un texto fílmico. Cátedra. 
Casetti, F. y Di Chio, F. (1991). Cómo analizar un film. Planeta.

Chatman, S. (1990). Historia y discurso: la estructura narrativa en la novela y en el cine. Taurus.

Cillóniz, A. (Ed.). (1989). Poesía hispanoamericana. Alborada.

De los Ríos, V. (2007). Literatura y tecnología en Darío, Oquendo de Amat y Palma. Romance Notes, 48(1), 91-99. https://doi.org/10.1353/ rmc.2007.0003

Eisenstein, S. (1926). Film Form Essays in Film Theory. Hartcourt.

Eisenstein, S. (1972 [1933]). Cinematismo. Domingo Cortizo Editor.

Elleström, L. (Ed.). (2010). Media borders, multimodality and intermediality. Springer.

Englund, A. (2010). Intermedial Topography and Metaphorical Interaction. En: L. Elleström (Ed.), Media borders, multimodality and intermediality (pp. 69-80). Springer.

Epstein, J. (1920). La poesía de hoy. Un nuevo estado de inteligencia. J. Samet.

Frank, J. (1991). Spatial form in modern literature, the idea of spatial form. Rutgers University.

Gómez de Tejada, J. (2017). Carlos Oquendo de Amat: el poema acéntrico como espacio lírico alternativo a la metrópolis moderna. Tonos Digital, (32), 1-23. http://hdl.handle.net/10201/51903

Gómez, N. (2008). La sombra de Charles Chaplin en César Vallejo. Espéculo: Revista de Estudios Literarios, 39. https://bit.ly/2E80hid

Hernández Les, J. A. (2005). Cine y literatura: Una metáfora visual. Ediciones JC Clementine.

Higgins, D. (1967). Statement of intermedia. En W. Vostell (Ed.), Décoll/age (décollage) 6. Typos Verlag. https://www.artpool.hu/Fluxus/ Higgins/intermedia2.html

Ibáñez, A. (2017). Letras de celuloide: una lectura de 5 metros de poemas de Carlos Oquendo de Amat. 452%F, (17), 173-190. https://bit.ly/3hgQRPI

Illouz, E. (2009). El consumo de la utopía romántica. Katz.

Kristeva, J. (1968). Poésie et negativité. L'Homme, 8(2), 36-63. https://doi. org/10.3406/hom.1968.366977 
Lauer, M. (2004). Musa mecánica. Máquinas y poesía en la vanguardia peruana. Instituto de Estudios Peruanos.

Meneses, C. (1973). Tránsito de Oquendo de Amat 1905-1936. Inventarios Provisionales.

Mitry, J. (1990). La semiología en tela de juicio (cine y lenguaje). Akal.

Monguió, L. (1954). La poesía postmodernista peruana. University of California Press.

Monguió, L. (2004). Un vanguardista peruano. En O. Aramayo y R. Milla (Eds.), Carlos Oquendo de Amat. Cien años de poesía viva. 1905-2005 (pp. 78-87). Fondo de Editorial Peruana.

Núñez Pacheco, R. (2006). Cinema poesía: un visionario llamado Carlos Oquendo de Amat. En A. Volantines (Coord.), Segundo Congreso de Poesía de la Región de Coquimbo y el Mundo Andino. https://bit. $1 y / 30 x 5 J m o$

Oquendo de Amat, C. (1985). Cinco metros de poemas. Orígenes.

Oviedo Pérez de Tudela, R. (2006). La imagen en Carlos Oquendo. Ómnibus: Revista Intercultural del Mundo Hispanohablante, 2(8), http:// www.omni-bus.com/n8/oquendo.html

Peña Ardid, C. (1992). Literatura y cine: una aproximación comparativa. Cátedra.

Pessis García, B. (2014). El cine, los sentidos y el mercado en 5 metros de poemas de Carlos Oquendo de Amat. Dialogía, (8), 4-21. https://bit. ly/2ZO3745

Sales Delgado, C. M. (2010). Ciudad y vanguardismo en "New York" de Carlos Oquendo de Amat. LL Journal, 5, 1. https://bit.ly/3hpvlbo

Sánchez Rodríguez, A. (1992). La inmolación perpetua de Carlos Oquendo de Amat. Scriptura, (8-9), 255-265. https://bit.ly/2WJceS2

Sánchez-Biosca, V. (2009). El montaje: entre cine, literatura y plástica. En C. Peña Ardid (Coord.), Encuentros sobre literatura y cine (pp. 93-108). Instituto de Estudios Turolenses. https://bit.ly/2CsRnvl

Siles Ojeda, B. (2000). Una mirada retrospectiva. Treinta años de intersección entre el feminismo y el cine. Caleidoscopio. Revista del AudioVisual, 1(1). https://bit.ly/3eKq10E 
Tynjanov, Y. (1971 [1927]). Fundamentos del cine. En Miguel Bilbatúa (Ed.), Cine soviético: Teoría y lenguaje (pp. 113-143). Alberto Corazón.

Urrutia Gómez, J. (2000). Cine y poesía. Príncipe de Viana. Anejo, (18), $405-$ 414. https://bit.ly/2WDMQgn

Valero Juan, E. (2008). Geografías de poesía y vida en los "Cinco metros" de Carlos Oquendo de Amat. Anales de Literatura Española, (20), 303 . 317. https://bit.ly/39gurv4

Vargas Llosa, M. (1983). La literatura es fuego. En Contra viento y marea (1962-1982) (pp. 132-137). Seix Barral.

Villaplana Ruiz, V. y Ortuño Mengual, P. (2018). Film Poetry. Repensando el cine de vanguardia: arte en movimiento y poéticas visuales. Revista de Comunicación de la SEECI, (47), 01-15. http://doi.org/10.15198/ seeci.2018.47.01-15 